\title{
Integrating Rhetorical Criticism into Business Communication as an Interdisciplinary Approach
}

\section{Sangchul Lee}

\author{
Sungkyunkwan University, Seoul, Korea
}

Objectives: The purpose of this paper is to suggest integrating rhetorical analysis and criticism into business communication research and pedagogy. Rhetorical analysis and criticism on public addresses of business leaders can provide important insights into the political and social issues of the community and the economic impact of the participants. Such an analysis would contribute to the development of communication scholarship taking place at the intersection of business communication, rhetoric, and society. Methods: This paper reviews articles on the rhetoric of business leaders published in business communication journals (e.g., Journal of Business Communication, Business and Professional Communication Quarterly, Management Communication Quarterly, Journal of Business and Technical Communication, Technical Communication Quarterly). It examines the purpose of rhetorical criticism in business communication and discusses popular criticism methods. Among the various perspectives on rhetorical criticism in the field of speech communication, this stduy discusses three commonly adopted methods - Neo-Aristotelian criticism, Genre Criticism, and Narrative criticism.

Results: Studies on the rhetorical criticism of speeches of business leaders are not systematically integrated into business communication education and research. Rhetorical critics of speech communication are more interested in public speeches by prominent politicians or social leaders, while business communication scholars are more concerned with rhetorical theory and pedagogy.

Conclusions: Integrating rhetorical criticism into business communication as an interdisciplinary approach infuses a new approach that goes beyond the domains of contemporary research and pedagogy. Integrating rhetorical criticism into business communication not only improves the quality of discourse in business society but also tests and modifies both the theory and practice of corporate rhetoric.

Key Words: Rhetorical Criticism, Business Speech, CEO Speech, Genre Criticism, Narrative Criticism

\section{Introduction}

In the various disciplines of humanities and social science, sub-

Received: Oct 19, 2018 Revised: Oct 28, 2018 Accepted: Nov 4, 2018

Corresponding author: Sangchul Lee

Sungkyunkwan University, Chongro-Ku, Seoul 03063, Korea

Tel: +82-2-740-1586, E-mail: scleemn@skku.edu

This is an Open Access article distributed under the terms of the Creative Commons Attribution Non-Commercial License (http://creativecommons.org/licenses/ by-nc/4.0/) which permits unrestricted non-commercial use, distribution, and reproduction in any medium, provided the original work is properly cited.

Copyright $\odot 2019$ Korean Association for Business Communication. ject areas can be divided into theory, practice, and criticism. In business communication, there has been tremendous progress in the rhetorical theory and practice of the last century. Much of the practical pedagogy for business presentations and speeches has been developed to educate students effectively. Business communication research has integrated rhetorical theory and practice into the study of business communication for decades. To be sure, numerous studies address rhetorical theory and practice in business communication, but relatively few works focus on rhetorical criticism.

Business corporations play an important role as participants 
in the economic, social, and political arena, while speeches of business leaders often have a significant impact on social and public affairs. The CEO is the most visible leader in a company. His or her public speeches can affect all facets of the company's culture, not just how people feel about the company but also how they perform. A CEO's speeches thus have a significant impact not only on the enterprise but also on employees, customers, and the general public. In particular, with the advancement of technology and international markets, the message of global CEOs is increasingly affecting the economic, social, and political life of people around the world. Therefore, it is important to extend research to the rhetorical analysis of CEO's public speeches. CEO's public speeches ought to be enough warrant for rhetorical criticism in the field of business communication. Still less scholars have paid much attention to rhetorical criticism on the public speeches of the business leader.

The first reason for the lack of research on business leaders' public speeches is that rhetorical scholars in the field of speech communication neglected the speeches of these business leaders. Rhetorical critics in speech communication tend to focus on public addresses of politicians or prominent great speakers in society and do not pay much attention to the speeches of business leaders. Cyphert (2010) points out that, since Herbert Wichelns launched rhetorical criticism in 1925, rhetorical scholars are more concerned with speeches of prominent social and political leaders. For a long time, Curti (1944) argued that speech communication should have produced more studies on the public addresses of business leaders, complaining about 'the omission of business addresses' in research (p. 485). Cheney (1992) lamented that the lack of a critical analysis of corporate rhetoric is "a remarkable harassment in contemporary rhetorical criticism" (p. 167). Cyphert pointed out that, in the top 100 modern speeches of the 20th century selected by rhetorical scholars (Lucas \& Medhurst, 1999), not even a single business leader's speech is included "on the basis of social and political consequences and rhetorical artistry" (p. 347).

The second reason is that business communication researchers have not paid much attention to the rhetorical criticism of business leaders' speeches. In the field of business communication, practical guides for presentations and public speeches are integrated into the basic course of business communication, but the rhetorical criticism of CEO's words and speeches is not yet widely studied. Employees and consumers are citizens. By influencing political representation and social justice, they will have much more impact on multinational corporations that support daily buying than they can by voting.

Recently, however, a number of business communication scholars assert that business communication should pay much more attention to the rhetorical criticism of the business leaders' public speeches. Several researches have examined the academic domain and impact of corporate rhetoric (Conrad, 2003; Deetz, 1992; May, Cheney, \& Roper, 2007), and more recently, others have investigated the theories and practice of the rhetoric of entrepreneurs (Gerding \& Vealey, 2017; Jones, 2017; Spinuzzi, 2017). Some researchers have critically discussed the proper role of corporate rhetoric in public decision-making (Matten \& Crane, 2005; Morrison, 2003; Saiia \& Cyphert, 2003). Some have also analyzed the speeches of business leaders; Hartog and Verburg (1997) analyzed the speaking styles of international business leaders, while McCarthy and Hatcher (2004) have published a rhetorical analysis of Fiorina and Rupert Murdoch's speeches. Study on rhetorical criticism on corporate apologia has additionally been strongly integrated into crisis management (Benoit, 1995; Coombs, 2014).

Integrating rhetorical criticism into business communication as an interdisciplinary approach infuses a new area that goes beyond the domains of contemporary research and pedagogy. The interdisciplinary approach incorporates separate disciplinary data, concepts, tools, methods, perspectives, and theories to create a holistic view or general understanding of complex issues, questions, and problems in business communication. The most obvious goal of rhetorical criticism may simply be to understand the impact of business speech on human affairs, especially modern economic, social, and political processes.

The purpose of this paper is to propose integrating rhetorical analysis and criticism into business communication research and pedagogy. Rhetorical analysis and criticism on the public addresses of business leaders can provide important insights into the political and social issues of the community and the economic impact of the participants. It contributes to the development of scholarship at the intersection of business communication, rhetoric, and society. This paper reviews articles on the rhetoric of business leaders published in business communication journals, including the Journal of Business Communication, Business and Professional Communication Quarterly, Management Communication Quarterly, Journal of Business and Technical Communication, and Technical Communication Quarterly. It discusses the purpose of rhetorical criticism in business communication and reviews popular methods for rhetorical criticism. Among the various perspectives on rhetorical criticism in the field of speech communication, three commonly adopted methods are reviewed and discussed-Neo-Aristotelian criticism, genre criticism, and narrative criticism. 


\section{Purpose of Rhetorical Criticism and Rhetorical Criticism in Business Communication}

In the Gettysburg Address, Lincoln said, "The world will little note, nor long remember what we say here, but it can never forget what they did here." Ironically, it is Lincoln' words that last long, and their deeds are recalled through his words. Corporates come and go with time, but the great CEO's deeds and words become immortalized. The words and speeches of CEOs motivate employees and help stakeholders, customers, and public see and believe in a vision. Rhetorical criticism in business communication gives us a better understanding of what is happening in the business world and enhances our understanding of how the CEO's public address produces an image of the corporation. One can better understand the impact of business leaders' speeches on society with rhetorical criticism.

In business communication, rhetorical criticism has resulted from being attracted to the obstacles in the speaker, subject, and business environment. It allows a better understanding of rhetorical practice and reveals the relationship between speakers, customers, employees, the general public, and society. Integrating rhetorical criticism into business communication sensitizes business communication students and teachers to stimulate critical thinking about a CEO's speech in various situations of rhetorical activity. However, in the history of speech communication itself, rhetorical criticism is a relatively modern product. For decades, various methods of rhetorical criticism have been developed to provide rhetorical critics with the necessary skills and perspectives to become a critically functioning critic. Still, there have been ongoing debates about 'what rhetoric criticism is' 'why critics should analyze public speech', and 'how to systematically do it.'

Rhetoric criticism of public addresses is the investigation and evaluation of speeches to understand rhetorical processes and its impact on society. Rhetorical criticism increases the capacity of readers to appreciate public addresses and enables the general audience to make informed and deliberate judgments based on persuasive appeals. Rhetorical criticism in business communication makes us better informed about what is going on in the business world and increases our understanding of how business communication influences our lives.

Rhetorical criticism is not like solving problems in science; it is primarily subjective rather than objective. Rhetorical criticism is a kind of argumentation and is a rhetorical act in its own right. The subjective evaluation of the speech may reflect the various perspectives that the critic adopts in his or her analysis. However, a rhetorical critic should create a sound case for evaluations and judgments that support rational and persuasive argument. Campbell and Burkholder (1997) provide four stages of rhetorical criticism in a public address: The first stage is "a descriptive analysis of the rhetorical act in terms that permit identification of means by which it works to influence"; description of the characteristics of purpose, persona, audience, tone, structure, supporting materials. The second stage is "a historical-contextual analysis of the relationships between discourse and its context to identify the forces that contribute to or work against its purposes." The third stage is "a development of a critical perspective, approach, or system that guides the finished critique." The fourth stage is "an evaluation and judgment of discourse based on explicit criteria so that grounds for evaluation are apparent readers" (p. 15). They introduce four standards or criteria for the evaluation of public addresses: the effects criterion, truth criterion, ethical criterion, and artistic criterion. Integrating rhetorical criticism into business communication not only improves the quality of discourse in business but also tests and modifies both the theory and practice of corporate rhetoric. In addition, it will promote a better understanding of business leaders' speech to students and teachers in business communication.

\section{Perspectives on Rhetorical Criticism}

\section{Neo-Aristotelian Approach}

In discussing the definition and scope of business communication, Reinsch (1996) metaphorically writes that "the putative mother of business communication, deposed former 'beauty' (rhetoric) [has] been invited her back onto dance floor" (p. 27). In fact, the principles of classical rhetoric have played an important role and provide a framework for teaching speaking and writing in business communication. Various classical rhetorical techniques are more than ancient concepts reserved for critics for both creating and analyzing efficient professional speech.

In 1925, Herbert Wichelns launched a pioneer essay on rhetorical criticism, "The literary criticism of the oratory," presenting a process of evaluating public speeches (Wichelns, 1925). He emphasizes that literary and rhetorical criticism have important differences, separating rhetorical criticism from the literary criticism of written English. He presents a new way to evaluate public speech. Wichelns argues that rhetorical criticism is distinguished from literary criticism, in which rhetorical criticism is 'not concerned with permanence, nor yet with beauty.' Rather, it is 'concerned with effect.' It is considered to be a speech as a communication with a particular audience and maintains a business that analyzes and evaluates the speaker's way of communicating his ideas to the audience. Rhetorical criticism may be a part of literary criticism but can also be regarded as 
an end itself. However, literary criticism tends to analyze the writer's personal and biological aspects. Literary criticism, full of personality and heart, has little interest in the audience and is behind the performance of speakers. Literary critics are more concerned with permanent wisdom, beauty, means of style in creative written work, or the author's personality. In a similar vein, there are some studies in business communication that are more interested in the personal history of CEOs than in a rhetorical analysis of CEO's speeches. Rhetorical criticism of CEO speeches should be more concerned with judgments, assessments, persuasive effect, occasion, relationships with speakers and audience, and means of persuasion.

Wichelns suggests that critics should examine the personality of the speaker, the public character of the speaker, the public perception of the speaker, the audience, the preparation of the speech, the organization of the speech, the major ideas and topics, the appeals, the proofs, the mode of expressions, the short term impact on the immediate audience, and the long term effects on the public and society. Wichelns' approach contains many of same topics discussed by Aristotle's Rhetoric and by other classical rhetoricians such as Cicero and Quintilian. Later, this approach is called neo-Aristotelian criticism. Wicheln's article has generated increasing research on speech criticism based on classical rhetorical concepts. From the 1920's to 1960's, the neo-Aristotelian method prevailed in rhetorical criticism.

Along the same line, studies on business communication show how classical rhetoric works in rhetorical analysis of business leaders' speeches. Crable (1990) analyzed organizational rhetoric based on classical perspectives. Hartog and Verburg (1997) investigated the charisma and ethos of international business leaders. The classical notions of the means of persuasion-ethos, pathos, and logos-are the fundamental concepts of neo-Aristotelian criticism; the speaker's personal credibility, capacity for stimulating the audience's emotions, and the use of logical appeals. Green (2004) drew on this familiar triad in the rhetorical tradition and concluded that the practice of the diffusion process by managers follows the rhetorical sequence, beginning with pathos, moving to the logos, and ending with ethos. Kallendorf and Kallendorf (1989) extended the Aristotelian concept of ethics to ethical communication about the rhetoric of business leaders by analyzing three case studies. Cheney, Christensen, Conrad, and Lair (2004) reviewed the key terms of classical rhetoric theory and applied them to organizational discourse. They presented the classical concept of enthymeme as an example for rhetorical analysis-"Apple urged consumers to 'Think different' in response to IBM's slogan 'Think"' (p. 92). Gerding and Vealey (2017) analyzed the rhetoric of civil entrepreneurs in a crowd funding case. Their detailed rhetorical analysis of crowd funding showed how to persuade or motivate investors and solve problems.

Neo-Aristotelian criticism was popular until the 1960s, when it was adopted into rhetorical criticism. However, there is criticism about the neo-Aristotelian approach; it simply focuses on the mechanical application of categories to rhetoric, with the result that critics are sometimes unimaginative and sum up how well the speech fits an a priori method. Hartelius and Browning (2008), in applying traditional rhetorical concepts to managerial research, asserts that when organizational rhetoric scholars wish to apply Aristotelian theory, they involve the historic reduction of rhetoric to a doctrinaire set of priori on the one hand, or a grammar on style on the other. Others criticize that Aristotle's rhetoric and other classical writings were written in an ancient time when values, orientation, and knowledge were vastly different from ours. In the 1960's, these criticisms led to a pluralism in approaches or methods for rhetorical criticism. Few critics would make use of the neo-Aristotelian approach these days; however, it is important to understand the basic component of the neo-Aristotelian approach. The neo-Aristotelian approach is a starting point in rhetorical criticism. It may be appropriate for beginning critics and will facilitate their understanding of the basic elements of rhetoric criticism. Moreover, Conrad and Malphrus (2008) advocate a return to the assumptions of the Aristotelian tradition, asserting that the neo-Aristotelian approach better identifies the ethics of the business world dominated by corporate power.

\section{Genre Criticism}

The origins of genre criticism can be traced back to Aristotle's Rhetoric. Aristotle (1991) provides three basic genres of rhetoric based on rhetorical situations: forensic (law courts), deliberative (legislative assembly), epideictic (public ceremony). This is the view that the main purpose of a speech is determined by the situation in which a speaker addresses an audience. Black (1965) has attempted to move away from Aristotle's rhetorical genres arguing that Aristotle's system is simply too logos-centered. Black proposes a new generic frame of reference and broadens Aristotle's notion of how a rhetorical situation makes rhetorical strategies available to a speaker and affects an audience. Bitzer (1968) sets forth a concept of "rhetorical situation... dictates the purpose, theme, method and style of the [speaker's] response" (p. 66). He introduced a 'rhetorical exigence' that "specifies the audience to be addressed and the change to be effected," and there are potentially constraining contextual elements such as "beliefs, attitudes, documents, facts, traditions, images, interests, motives" as well as the speaker's personal character and style (pp. 63-65). They viewed rhetorical situations as recurring to 
generate genres. Black's outline of a new generic taxonomy and Bitzer's notion of rhetorical situation largely contributed to the development of generic criticism. In Form and Genre: Shaping Rhetorical Action, Campbell and Jamieson (1978) provide concise and comprehensive explanations of rhetorical genre. They define rhetorical genre as a fusion of elements formed from a constellation of forms, such as substances, strategic characteristics, stylistic features, and organizing principles.

Genre criticism is based on the assumption that similar types of situations provide similar needs and expectations among the audience. Generic critics seek to discover communalities in rhetorical patterns across recurring situations. They are interested in the relationship between recurring situations and the contents of speech developed in response to them. Generic criticism enables critics to understand social reality and its relationship to rhetoric. Generic criticism spawned numerous studies in the field of speech communication and influenced the development of crisis rhetoric in business communication.

Kallendorf and Kallendorf (1985) have explored the importance of genres of CEO speeches. They attempt to formulate a satisfactory description of the main end of all business communication, including speeches. They conclude that the main end of business communication is to activate audience responses that contribute to a company's commercial success. CEOs want persuasive messages to manage external crises, to allay employee concerns about major internal changes such as restructuring and layoffs, or to report on the company's financial performance to the stakeholders and public. Crable and Vibbert (1983) adopted the classical concept of epideictic genre to assess Mobile's CEO's strategy to delight the public and inspire the employees while Rogers (2000) extended organizational genre through competing values and employee needs.

Thro (2009) modified Aristotle's speech genres for modern business settings. He extended the genres of CEO speeches by examining a number of contemporary speeches given by CEOs. He differentiates features of business speech genres that together account for a large number of corporate speeches. He argues that "it is certainly at odds with my own experience of corporate speaking practice.... I will propose modification of the present accounts" (p. 336). He proposed hybrid structures and genres of the business speeches. He identified CEO speech genres that are formed according to their ends: single-purpose speech and hybrid speech. He explained fours single-purpose speeches: i) a report on a company's financial status to the investor community, ii) a crisis management speech to a concerned external public or to employees, iii) a policy advocacy speech to influential the public, iv) a discussion of company progress and prospects with the employees. He demonstrated that CEO speakers construct hybrid speeches by modifying single-purpose speech types regularly used in business and in other occasions. A typical hybrid speech genre is an educational conference speech to an audience interested in the business and a commendation ceremony speech for business teammates. Recognizing the CEO's speech genre is important to understanding organization, style, and strategy and to developing the appropriate standards to assess it.

One of the early adopters of genre criticism in business communication is crisis communication scholarship. Ware and Linkugel (1973) have extended the ancient forensic genre, which is categoria (accusation)-apologia and have analyzed the characteristics of self-defense speeches. They develop four major 'strategies' in apology (denial, bolstering, differentiation, and transcendence) and four major 'postures' (absolution, vindication, explanation, and justification). These classifications give researchers of corporate apologia a means to identify specific strategies and tactics that CEOs use to defend themselves and their corporates against accusations. Dionisopolous and Vibbert (1988) presented the first published work that discussed corporations engaging in apologia, thereby creating the concept of corporate apologia. Benoit (1995) modified classical concepts of stasis theory and developed the 'image restoration theory' by integrating ideas from corporate apologia and account giving. Account giving is an interpersonal apology. Allen and Caillouet (1994) extended account giving to organizations. One of the main goals of corporate apologia is to defend the reputation of the organization. Hearit $(1994,2006)$, in an analysis of apologies by Chrysler, Toshiba, and Volvo, argued that crisis threatens corporate social legitimacy, as stakeholders think the company is responsible for the crisis. He developed three dissociation strategies: opinion-knowledge, individual-group, and act-scene. Ulmer, Seeger, and Sellnow (2007) introduced the 'rhetoric of renewal' in corporate crisis, helping victims and projecting a positive future for the organization and stakeholders.

Corporate apologia is crucially related to the crisis response strategy, and the crisis manager speaks and acts after the crisis. Rhetorical critics consider how the crisis response strategy is crafted. Frandsen and Johansen (2012) suggest the concept of the 'rhetorical arena' and note that there are many ways to express denial or rebuild the image of the corporation. Corporations have public characters that are reputations, just like individuals. Reputations can be defined as how people perceive the organization. Reputations are evaluative and are created when people recognize the accumulated information, messages, and actions of the company (Caroll \& McComs, 2003; Fombrun \& van Riel, 2004). In a crisis situation, the rhetoric of the CEO not only structures the meaning of a particular social and business reality but also reflects the beliefs, attitudes, and values, arising 
out of that reality.

Genre is closely associated with corporate apologia strategies. Each tactic or strategy has its own conventions, which serve to shape and filter the crisis communication message it delivers. Genre criticism will be a useful framework for analyzing CEO speeches in crisis business communication. For example, in a recent 'data-privacy' crisis, Facebook CEO Mark Zuckerberg's speech is a good case to analyze with generic criticism. However, it is important to note that classifying genre is not criticism in itself but does allow critics to discover strategies that recur in a particular type of rhetoric. In other words, genre classification comes before the actual criticism.

\section{Narrative Criticism}

Narrative has been well understood as a rhetorical technique since ancient times (Fisher, 1989). Fisher (1989), however, goes beyond that and claims that narrative is a discrete persuasive technique. He assumes that all forms of human communication can be seen fundamentally as stories, as interpretations of aspects of the world occurring in time and shaped by history, culture, and character. He asserts that stories are fundamental to communication because they provide structure for our experience as humans and because they influence people to live in communities that share common explanations and understandings. Narrative is a way of ordering and presenting a view of the world through a description of a situation involving characters, actions, and settings that change over time. The narrative impulse is part of our being, and narratives are meaningful for everyone across culture, time, and place. Finally, in rhetorical criticism, he proposes a critical framework for assessing narratives based on the concepts of narrative 'probability' and 'fidelity.' He defines 'narrative paradigm' as a philosophical statement that is meant to offer an approach to interpretation and an assessment of human communication.

Organizational communication scholars immediately recognized the importance of narrative. Weick and Browning (1986) investigate how different types of communication create different organizational forms. They concluded that the narrative paradigm connects facts, stores complex summaries in retrievable form, and helps people comprehend complex environments. Gabriel (2004) argues that narrative is a reliable sense-making process in organizational communication. A storyteller has choices in the poetic tropes such as the attribution of motive and the attribution of causal connections. He or she would mold the facts to fit the plot through framing, concentrating, filtering, etc. Brown (2006) suggests that narrative is fundamental to the construction of identity, and O'Connor (2002) provides a typology of entrepreneurial narratives. By examining the narrative structure of business communication, management scholars conclude that narrative is an underlying structure supporting both business practices, and it is at once a means of participating in rational discourse and organizational myth (Barry \& Elmes, 1997; Hopkinson, 2003). In short, narratives are modes of participating in and making sense of cultural life in business communication.

Emphasizing the power of narrative in a CEO's speech, Baldoni (2013) asserts that narrative captures the attention of the audience, informs people by bringing the facts to life, involves individuals by appealing to their interests, and inspires the audience members to take action. Jones (2017) identifies narratives of economic, community, legacy, and social justice empowerment. Jones analyzes the narratives of successful black entrepreneurs and explores how black business owners rhetorically position themselves for success, sustainability, and empowerment. Duarte (2018) argues that narrative is crucial in understanding the workings of a great CEO speech. A good CEO relies on a variety of communication tools to encourage teams and influence others to take action, while some CEOs tend to give presentations and speeches that offer impressive statistics and industry news to persuade. A personal story, narrative, is a powerful and convincing tool. Duarte claims that Starbucks former CEO Howard Schultz is one of the best storytelling executives. Schultz uses the narrative of childhood misfortune to frame the corporate value and direction of Starbucks. Another good example of narrative executive is Rowan Trollope, SVP at Cisco, frequently opening his speeches with a story of his past experiences to show his humility or humanity.

CEOs that succeed in delivering speeches to reinforce presentations and inspire organizations show their true selves in narrative. When an executive plans to deliver an important talk, he or she may consider pulling from his or her own memory of personal stories first. By focusing on narrative about who he or she is and what he or she has overcome, he or she can inherently build trust with listeners and encourage them to adopt new ways of thinking or take action. With a personal story, CEOs want to show that they understand the wants, needs, and impulses of listeners. Then, he or she creates products or devices that delight users, whether they are professionals in the industry or just picking up the technology for the first time. CEOs often use narrative to emphasize corporate values and goals in their speeches. Narratives and stories are not merely entertainment, but they are ways of interpreting and evaluating experience in a business speech situation. 


\section{Conclusion}

Business communication has a long history, stretching back to the origins of rhetoric as a scholarly endeavor. Today, rhetorical theory and practice guides in business communication are well integrated into undergraduate courses that emphasize writing and speaking instruction for business students. For the future, business communication should continue to emphasize and improve education in rhetorical criticism as an interdisciplinary approach while it strives to produce more research on the rhetorical analysis of business leaders' speeches. Integrating rhetorical criticism into business communication expands and strengthens its research efforts and enlarges the pedagogical domain

\section{References}

Allen, M. W., \& Caillouet, R. H. (1994). Legitimation endeavors: Impression management strategies used by an organization in crisis. Communication Monographs, 61(1), 44-62.

Aristotle (1991). On rhetoric: A theory of civic discourse (G. A. Kennedy, Trans.). New York, NY: Oxford University Press.

Baldoni, J. (2013). The leader's guide to speaking with presence: How to project confidence, conviction, and authority. New York, NY: AMACOM.

Barry, D., \& Elmes, M. (1997). Strategy retold: Toward a narrative view of strategic discourse. Academy of Management Review, 22(2), 429-452.

Benoit, W. L. (1995). Accounts, excuses, and apologies: Image repair theory and research. Albany, NY: State University of New York Press.

Bitzer, L. F. (1968). Rhetorical situation. Philosophy and Rhetoric, 1(1), 1-14

Black, E. (1965). Rhetorical criticism: A study in method. Madison, WI: University of Wisconsin Press.

Brown, A. D. (2006). A narrative approach to collective identities. Journal of Management Studies, 43(4), 731-753.

Campbell, K. K., \& Burkholder, T. R. (1997). Critiques of contemporary rhetoric. Belmont, CA: Wadsworth.

Campbell, K. K., \& Jamieson, K. H. (1978). Form and genre: Shaping rhetorical action. Falls Church, VA: Speech Communication Association.

Cheney, G. (1992). The corporate person (re) presents itself. In E. L. Toth \& R. L. Heath (Eds.), Rhetorical and critical approaches to public relations (pp. 165-183). Hillsdale, NJ: Lawrence Erlbaum Associates.

Cheney, G., Christensen, L. T., Conrad, C., \& Lair, D. J. (2004). Corporate rhetoric as organizational discourse. In D. Grant, C.
Hardy, C. Oswick, \& L. Putnam (Eds.), The Sage handbook of organizational discourse (pp. 79-102). London, UK: Sage.

Conrad, C. (2003). Stemming the tide: Corporate discourse and agenda denial in the 2002 corporate meltdown. Organization, 10(3), 549-560.

Conrad, C., \& Malphurs, R. (2008). Are we there yet? Are we there yet? Management Communication Quarterly, 22(1), 123-146.

Coombs, W. T. (2014). Applied crisis communication and crisis management: Cases and exercises. Los Angeles, CA: Sage.

Crable, R. E. (1990). 'Organizational rhetoric' as the fourth great system: Theoretical, critical, and pragmatic implications. Journal of Applied Communication Research, 18(2), 115-128.

Crable, R. E., \& Vibbert, S. L. (1983). Mobil's epideictic advocacy: 'Observations' of prometheus-bound. Communication Monographs, 50(4), 380-394.

Curti, M. (1944). Brigance: A history and criticism of American public address. American Historical Review, 49(3), 485-486.

Cyphert, D. (2010). The rhetorical analysis of business speech. The Journal of Business Communication, 47(3), 346-368.

Deetz, S. A. (1992). Democracy in an age of corporate colonization: Developments in communication and the politics of everyday life. Albany, NY: State University of New York Press.

Dionisopolous, G. N., \& Vibbert, S. L. (1988). CBS vs mobil oil: Charges of creative bookkeeping in 1979. In H. R. Ryan (Ed.), Oratorical encounters: Selected studies and sources of twentieth-century political accusations and apologies (pp. 241-252). Westport, CT: Greenwood.

Duarte, N. (2018). The secret behind authentic and persuasive CEO speeches. Forbes. Retrieved from https://www.forbes.com/ sites/committeeof200/2018/10/23/the-secret-behind-authenticand-persuasive-ceo-speeches/\#6dd7f55374f0

Fisher, W. R. (1989). Human communication as narration: Toward a philosophy of reason, value and action. Columbia, SC: University of South Carolina Press.

Fombrun, C. J., \& van Riel, C. B. M. (2004). Fame \& fortune: How successful companies build winning reputations. Upper Saddle River, NJ: Pearson Education.

Frandsen, F., \& Johansen, W. (2012). Crisis communication, complexity, and the cartoon affairs: A case study. In W. T. Coombs \& S. J. Holladay (Eds.), The handbook of crisis communication (pp. 425-448). Malden, MA: Wiley-Blackwell.

Gabriel, Y. (2004). Narratives, stories and texts. In D. Grant, C. Hardy, C. Oswick, \& L. Putnam (Eds.), The Sage handbook of organizational discourse (pp. 61-78). London, UK: Sage.

Gerding, J. M., \& Vealey, K. P. (2017). When is a solution not a solution? Wicked problems, hybrid solutions, and the rhetoric of civic entrepreneurship. Journal of Business and Technical Communication, 31(3), 290-318. 
Green, S. E., Jr. (2004). A rhetorical theory of diffusion. Academy of Management Review, 29(4), 653-669.

Hartelius, E. J., \& Browning, L. D. (2008). The application of rhetorical theory in managerial research: A literature review. Management Communication Quarterly, 22(1), 13-39.

Hartog, D. N., \& Verburg, R. M. (1997). Charisma and rhetoric: Communicative techniques of international business leaders. Leadership Quarterly, 8(4), 355-391.

Hearit, K. M. (1994). Apologies and public relations crises at Chrysler, Toshiba, and Volvo. Public Relations Review, 20(2), 113125.

Hearit, K. M. (2006). Crisis management by apology: Corporate response to allegations of wrongdoing. Mahwah, NJ: Routledge.

Hopkinson, G. C. (2003). Stories for the front-line: How they construct the organization. Journal of Management Studies, 40(8), 1943-1969.

Jones, N. N. (2017). Rhetorical narratives of black entrepreneurs: The business of race, agency, and cultural empowerment. Journal of Business and Technical Communication, 31(3), 319-349.

Kallendorf, C., \& Kallendorf, C. (1985). The figures of speech, ethos, and Aristotle: Notes toward rhetoric of business communication. Journal of Business Communication, 22(1), 35-50.

Kallendorf, C., \& Kallendorf, C. (1989). Aristotle and the ethics of business communication. Journal of Business and Technical Communication, 3(1), 54-69.

Lucas, S. E., \& Medhurst, M. J. (1999). American rhetoric top 100 speeches. Retrieved from http://www.americanrhetoric.com/ index.htm

Matten, D., \& Crane, A. (2005). Corporate citizenship: Toward an extended theoretical conceptualization. Academy of Management Review, 30(1), 166-179.

May, S., Cheney, G., \& Roper, J. (Eds.). (2007). The debate over corporate social responsibility. Oxford, UK: Oxford University Press.

McCarthy, P., \& Hatcher, C. (2004). Reputation building: The pub- lic communication styles of Carly Fiorina and Rupert Murdoch. Australian Journal of Communication, 31(1), 1-18.

Morrison, J. (2003). Corporate citizenship: More than a metaphor? Journal of Corporate Citizenship, 10(2), 89-102.

O'Connor, E. (2002). Storied business: Typology, intertextuality, and traffic in entrepreneurial narrative. The Journal of Business Communication, 39(1), 36-54.

Reinsch, N. L. Jr. (1996). Business communication: Past, present, and future. Management Communication Quarterly, 10(1), 27-49.

Rogers, P. S. (2000). CEO presentations in conjunction with earnings announcements: Extending the construct of organizational genre through competing values profiling and user-needs analysis. Management Communication Quarterly, 13(4), 426-485.

Saiia, D. H., \& Cyphert, D. (2003). The public discourse of the corporate citizen. Corporate Reputation Review, 6(1), 47-57.

Spinuzzi, C. (2017). Introduction to special issue on the rhetoric of entrepreneurship: theories, methodologies, and practices. Journal of Business and Technical Communication, 31(3), 275-289.

Thro, A. B. (2009). CEOs' hybrid speeches: Business communication staples. The Journal of Business Communication, 46(3), 335361.

Ulmer, R. R., Seeger, M. W., \& Sellnow, T. L. (2007). Post-crisis communication and renewal: Expanding the parameters of post-crisis discourse. Public Relations Review, 33(2), 130-134.

Ware, B. L., \& Linkugel, W. A. (1973). They spoke in defense of themselves: On the generic criticism of apologia. Quarterly Journal of Speech, 59(3), 273-283.

Weick, K. E., \& Browning, L. D. (1986). Argument and narration in organizational communication. Journal of Management, 12(2), 243-259.

Wichelns, H. A. (1925). The literary criticism of oratory. In A. M. Drummond (Ed.), Studies in rhetoric and public speaking in honor of James Albert Winans (pp. 181-216). New York, NY: The Century Company. 